\title{
Translating Word Order Variations in the Qur'an: A Qualitative and Quantitative Assessment
}

Ahmed Saleh Elimam (Corresponding author) School of Arts, University of Leicester, UK

Email: ase5@le.ac.uk

Received: $16 / 08 / 2020$

Accepted: 05/10/2020

Published: 01/11/2020

Volume: 1 Issue: 4

How to cite this paper: Elimam, A. S. (2020). Translating Word Order Variations in the Qur'an: A Qualitative and Quantitative Assessment. Journal of Critical Studies in Language and Literature, 1(4), 1-12

DOI: https://doi.org/10.46809/jcsll.v1i4.37

Copyright (C 2020 by author(s) and Global Talent Academy Ltd. This work is licensed under the Creative Commons Attribution International License (CC BY 4.0).

http://creativecommons.org/licenses/by/4.0/

(c) (9)

\begin{abstract}
Marked, unconventional word order is one of the most pertinent stylistic features of the Qur'an, and is employed to realise certain discursive functions. This article identifies the verses which foreground a lexical item to (or towards) sentence-initial position, resulting in a marked word order, as well as the functions realised thereby, drawing on classical commentaries on the Qur'an. Two of the most important English translations of the Qur'an by Abdel Haleem (2004/2005) and Arberry $(1955 / 1998)$ are selected for closer examination of the strategies they use to deal with the corpus of verses. The discussion is carried out against the backdrop of the translators' stated aims and reviews of their output. Furthermore, the potential influences of the translators' motivations, target readers' expectations, and the historical context of their work on their respective output are also discussed.
\end{abstract}

Keywords: Qur'an Translation, Marked Word Order, Translation Strategies, Context in Translation

\section{Introduction}

The literature on al-balāgha (the art of Arabic eloquence) and tafsìrs (commentaries or exegesis of the Qur' an) emphasise that the style of the Qur' an is "beautiful" (Guillaume, 1956/1990, pp.73-74), "eloquent" (al-Bāqillān̄, as cited in Vasalou, 2002, p.34; al-Jurjānī, as cited in Vasalou, 2002, p.39; Ayoub, 1984, p.2) and "inimitable" (Ayoub, 1984, p.2). Therefore, Qur'anic scholars, and translators for this matter, argue that the stylistic uniqueness of the Holy Book cannot be communicated through translation. For this reason, some translations feature words like "message," as in Muhammad Asad's The Message of the Qur'an (1980), or "meaning," as in A.Y. Ali's The Meaning of the Holy Qur'an (1934-7), or a combination such as "meaning" and "interpretation," as in Hilali and Khan's Interpretation of the Meaning of The Noble Qur'an (1977/1998), to signal the fact that these translations are considered interpretations of, rather than a substitute for, the Qur'an itself. This is also in line with Muslim belief that the Qur'an is the literal word of God which was revealed to the Prophet Muhammad in Arabic (e.g. Qur'an 12: 2) and that the purpose of any translation of it is to cater for the needs of nonArabic speaking Muslims, and to present Islam to non-Muslims, rather than to act as a substitute for the original. 
The stylistic uniqueness of the Qur'an has been subject to many studies which attempt to identify the stylistic features that make the Book special and different from other types and genres of Arabic writing (Elimam, 2009; 2013). Word order variations, resulting in marked, unconventional word orders, are one of the most distinctive aspects of Qur'anic style. From a classical perspective, which continues to provide the basis for understanding the issue of word order variation, al-Jurjānī (d. 1078 or $1081 \mathrm{CE}$ ) argues that sentence construction, which he calls "nazm" and defines as the arrangement of words in a sentence in light of their syntactical relationships with each other, is the basis and primary requirement for other types of Qur'anic balāgha features. These include a) simile "tashbīh," which includes analogy "tamthīl," b) figurative speech or allegory "majāz," which includes metaphor "isti 'āra" and hypallage "majāz mursal," and c) allusion or implication "kināya." These categories, which have become the basic components of the "Arabic science of eloquence," or "ilm al-balägha" by alSakkākī (d. 626/1229) and al-Qazwīnī (d. 739/1338) (Harb, 2015, p.302), all require "to be combined with other words in a sentence. It is because of it [i.e. word order] and through it that they function, for you cannot imagine any of these [indirect signs] entering speech as single entities without considering their syntactical [context]" (al-Jurjān̄, as cited in Harb, 2015, p.308). Therefore, word order is the way in which an idea can be expressed, and all the other stylistic and balägha aspects realised, hence its unique importance.

The importance of this research derives, first of all, from the fact that it examines one of the most important features of the Qur'anic style, namely word order variation, resulting from foregrounding a lexical item to or towards verse-initial position. Secondly, this stylistic feature is indeed challenging for translators, not least because Arabic word order is more flexible than English word order, and the strategies used to deal with the relevant verses can make the translations of the Qur'an read very differently from each other, which can confuse the readers as to why this is the case. Thirdly, creating a representative corpus of all the verses discussed primarily by al-Bayḍāwī's commentary, and complemented with other classical commentaries, will enable a systematic and comprehensive investigation of the issue to be carried out and offer insights into how and why two of the most important and popular translations of the Qur' an deal with this issue. Finally, this unique methodology will allow for qualitative and quantitative conclusions to be made about the translation strategies used, as well as the frequency and consistency of their use.

To fulfil the aim of this article, namely to identify the selected translators' strategies and reasons for rendering the Qur'anic verses featuring marked word order, I will:

- build a corpus of all the verses discussed in al-Bayḍāwī’s and other classical commentaries as examples of marked word order,

- examine, qualitatively and quantitatively, the strategies employed by the selected translators to render the functions of the verses' marked word orders into English, and

- investigate the contextual factors that may have influenced the translators' choice of strategies.

\section{Word order in Arabic/the Qur'an and English}

While English is an analytic language which creates syntactic relationships by word order and function words, Arabic is synthetic, which shows these relationships through the use of elaborate inflected forms (see Abdul-Raof, 2013). In English, the order of elements in clauses is relatively fixed, and the regular, canonical word order is subject-verb-object (SVO), and the meaning of the sentence depends mostly on the order in which its elements are arranged. In Arabic, although the canonical word orders are verb-subject-object (VSO) and subject-predicate (SP) (the latter is used when there is no verb in the sentence), there are few restrictions on word order thanks to elaborate verb inflection and case marking systems. This flexibility allows for the foregrounding of some lexical elements within the sentence to realise certain discursive functions (e.g. Lee, 2003; Choi, 1996). Each word has its regular position in the linear order of the Arabic sentence, meaning that there are canonical, default structures, VSO and SP, which are assumed to be followed unless the writer or speaker wishes to foreground some element/s of the sentence for a particular purpose (see al-Lāwindī, 2001; Lāshīn, 1978). This stylistic feature, called (التقديم و التأخير) “al-taqdīm wa al-ta'khīr" ("foregrounding and backgrounding”), is used primarily to highlight specific elements in the sentence. Word order variation is Arabic's unique way of delivering meanings in terms of their importance from the speaker's perspective, making the style a true reflection of his or her mind and feelings (Lāshīn, 1978, p.217).

Furthermore, Lee (2003, p.618) explains that "[i]n languages with fairly free word order, non-canonical [marked] orderings are preferred options to mark a special information structure." For example, marked word order is employed in Arabic "to give the predicate an emphatic effect" in SP/nominal sentences (Cantarino, 1974, p.31) and "to achieve an emphatic effect upon the subject" in verbal sentences (ibid, p.42). Similarly, Moutaouakil (1989) argues that the element with the pragmatic function of "contrastive focus" generally occupies sentence-initial position. In other words, the ordering of elements in clauses in Arabic is largely a matter of stylistic consideration and is employed to achieve thematic progression, signal emphasis, care and contrast and to organise messages in a variety of ways (see the functions below). The relevant functions are, therefore, important to take into consideration in translation since they have a specific stylistic purpose and an effect on meaning (Badawi et al., 2004).

In English, on the other hand, Leech and Short (1981, p.254) define foregrounding as "the violation of textual expectations." In a similar vein, Cuddon (1991, p.349) argues that foregrounding refers to "the use of devices and techniques which 'push' the act of expression into the foreground so that language draws attention to itself." Cuddon seems to suggest 
that foregrounding is used for aesthetic reasons or to attract the reader's attention, not to what is being said, but to the way it is said (see Carter, 2004). Leech (1970) proposes a dichotomous model for the study of foregrounding: "paradigmatic" and "syntagmatic." Paradigmatic foregrounding involves "the selection of an item not permitted or expected at a particular point," whereas syntagmatic foregrounding is "the repeated selection of an item where a single selection is expected" (in Martín-Asensio, 2002, p.54). Along the same lines, Halliday (1973/2002, p.112/98) defines foregrounding as "prominence that is motivated... [which] contributes to the writer's total meaning." It is clear here that the common denominator between the definitions above is the notion of selection/motivation, which relates to the third aim of this article stated above.

Under what constitutes lexical foregrounding specifically, Martín-Asensio (2002, p.174) considers this feature as "a cluster concept including aspectual contrasts, clause structure, 'given' and 'new' elements, and other features of language." He explains that the three major methods of foregrounding examined by scholars in recent times are: aspectual contrast, the fronting of explicit subjects in the clause and transitivity patterns (ibid). Martín-Asensio looks into foregrounding at the clause-level as well as text-level. The latter, alternatively called parallelism by Jakobson, does not fall within the scope of this study, which is concerned with lexical foregrounding at clause level. Finally, in English, foregrounding is used to cover, amongst other things, inversion, quotation inversion, argument-reversal, preposing and postposing, there-insertion, and cleft and pseudo cleft structures (Swan, 2005; Birner and Ward, 1998; Quirk, 1997; Green, 1982). Some theorists use these terms to refer to relatively different notions; others use them more or less interchangeably (see Elimam, 2013).

As such, lexical foregrounding is a language-specific device: it sets up relations which are conducive to the semantic cohesiveness of the text, and it is often difficult for two languages with different basic word orders and typologies (analytic versus synthetic), like Arabic and English, to achieve similar foregrounding effects through the same means in translation.

\section{Verses and Their Respective English Translations}

All verses discussed as examples of marked word order by al-Bayḍāwī primarily, but also in other classical commentaries by al-Rāzī (d. $1209 \mathrm{CE}$ ), al-Suyūṭi (d. $1505 \mathrm{CE}$ ) and al-Zamakhsharī (d. $1144 \mathrm{CE})$, have been identified through an electronic search of their commentaries on the Qur'an (www.greattafsirs.com). Al-Bayḍāwī's, a linguistic-oriented commentary, is selected as the primary source of data because it is not contested by modern writers with respect to his views on the albalāgha aspects of the Qur'an. Arabic scholars (e.g. al-Suyūtī, 1505/1909) recognise the importance of al-Bayḍāwī’s work, and European scholars regard it as "the standard commentary on the Qur' an" (Bell, 1970, p.169). According to Bell, this commentary was intended as a "manual for instruction in colleges or mosque-schools and therefore aims at giving in concise form all that was best and soundest in previous commentaries, including important variant interpretations" (1970, p.169; see also Elimam, 2013).

According to al-Bayḍāwī (and other commentators), marked word order features in 68 verses, 9 of which have two cases of foregrounding (i.e. 77 cases in total), realising a number of functions. These functions and the number of verses they feature in are summarised in table 1 below (see section IV for definitions of these functions).

Table 1: the number of verses per function according to the commentators

\begin{tabular}{|l|l|}
\hline Function & $\begin{array}{l}\text { Number of verses } \\
\text { (cases of foregrounding) }\end{array}$ \\
\hline Specification & $18(21$ cases $)$ \\
\hline Restriction & $5(6$ cases $)$ \\
\hline Emphasis & $25(26$ cases $)$ \\
\hline Amplification/glorification & 2 \\
\hline Denial & $6(7$ cases $)$ \\
\hline Multiple functions & $12(15$ cases $)$ \\
\hline
\end{tabular}

Two translations of the Qur'an into English are selected for analysis: Abdel Haleem (2004/2005) and Arberry (1955/1998). These are chosen because they are complete, rather than partial, to allow for the examination of all the corpus examples, and direct to avoid the problems associated with indirect translations via a third language. Furthermore, each states its translation approach; the first is communicative, and the second is literal, and therefore their respective styles are quite distinct. This is important in identifying whether or not the strategies they use are in line with their stated approach. In addition, the first translation is the most common translation read by lay readers (e.g. Elimam, 2017; Kidwai, 2007), whilst the second is the most common choice among academics. Finally, Abdel Haleem was awarded an OBE in 2008 for his publications, most notably his translation of the Qur'an; and Arberry's has been described as the best translation by a nonMuslim western scholar of Islam (Kidwai, 2007, 1987; Mohammed, 2005). Below is a brief description of each of these translations.

\subsection{Abdel Haleem's The Qur'an (2004/2005)}

Abdel Haleem, who memorised the Qur'an as a child, studied at the Islamic University of Al-Azhar, Cairo and at Cambridge University. He has taught Arabic, translation and Islamic studies at Cambridge University and London University since 1996 (Abdel Haleem, 2004/2005). Abdel Haleem states that his aim is "to go further than previous works in accuracy, 
clarity, flow, and currency of language" (2005, p.xxix). To do this, he has used "a modern, easy style, avoiding where possible the use of cryptic language or archaisms that tend to obscure meaning...to make the Qur' an accessible to everyone who speaks English" (ibid). He further points out that special attention has been paid to potentially problematic areas: intertextuality, context, specific aspects of Arabic structure and idiom, pronouns, classical usage, paragraphing and punctuation (2004/2005, p.xxix). Footnotes are only supplied when "absolutely necessary to clarify meaning and context" (ibid, p.xxxv). In addition, this translation divides the undivided, continuous Qur' anic text into paragraphs: "[i]n order to clarify the meaning and structure of thoughts and to meet the expectation of modern readers" (ibid, p.xxxiv). The translator also lists the works he drew on, including Al-Bayḍāwī's commentary, which is the main source of the Arabic data adopted here. Abdel Haleem (2008a, 2004a) emphasises that he avoids literalness in rendering Arabic structures and expression, noting that any translation of the Qur'an only attempts to render some of the meanings of the original whose inimitable literary nature cannot be rendered into another language. Sardar (2004) admires Abdel Haleem's use of “contemporary English," noting that the translation does not inspire a sense of poetic beauty, but argues that in a translation of a "text as rich and complex as the Qur'an, you cannot expect to have everything."

3.2. Arberry's The Koran (1955/1998)

Arberry (1905-69) graduated from Cambridge University, where he learnt Arabic and Persian. He was professor of classics at Cairo University, professor of Persian at the University of London, and then professor of Arabic at Cambridge University. Arberry aims "to improve on the performance of [his] predecessors, and to produce something which might be accepted as echoing however faintly the sublime rhetoric [he seems to mean 'eloquence'] of the Arabic Koran" (1955/1998, p.x). He describes earlier translations as "dull and flat indeed in comparison with the splendidly decorated original" (ibid) and explains that, unlike earlier translations which adopt the prose-like format of the original, his translation is verse-like so that "some faint impression may be given of its [i.e. the Qur' an's] dramatic impact and most moving beauty" (ibid, p.xii). He also adds that the grouping of verses into paragraphs is an attempt to reproduce their respective rhythm (ibid, p.x). This strategy, however, is not justified considering that the Qur'anic fäșila (end-of-verse-sound) he hoped to mirror does not follow this structure of five verses. Arberry also avoids the "Biblical style", footnotes and glosses in order to reproduce "the smooth flow of the Arabic Koran" (ibid). Kidwai (1987) maintains that Arberry's translation "stands out above the other English renderings by non-Muslims in terms of both its approach and quality", although it "is not altogether free from mistakes of omission and mistranslation.” For example, Arberry mistranslates (النبي الأمي) (Qur'an 7: 157), “the unlettered prophet" (Abdel Haleem, 2004/2005, p.105), as "the Prophet of the common folk." Bausani (1957, p.79) quotes critics of Arberry's translation who describe it as "a conscientious but slavish faithfulness to the letter... [which] has in general excluded any corresponding reflection of the spirit." Burton $(1969,387)$ describes the translation as "obscurer" because of its literal approach.

\section{The Discursive Functions of Verses and Translation Strategies}

Drawing on Elimam (2009 and 2013), who expounds the issue of word order variations in Arabic poetry and the Qur'an, this section defines, and illustrates with examples, the functions realised by the marked word orders of the corpus verses specifically. To avoid repetition, one example of each function is discussed below, and a summary of the strategies employed in each translation is provided in table 2. The analysis starts with a definition of the function in question, based on the commentaries mentioned above, followed by a detailed explanation of the relevant verse's structure, how each translation renders the verse's word order and whether or not the strategies used reproduce the stylistic function of the original.

4.1. Specification (التخصنص or التخصاص)

Al-Bayḍāwī and al-Suyūṭi (1969, p.191ff) define Specification as (تعلق خاص), special reference/attachment, and ( قصد الخاص (من جهة خصوصه ; that is referring to a specific aspect of the entity concerned. An entity can be referred to from an aspect it shares in common with other entities, or from a specific aspect which differentiates it from other entities: it is the latter that is referred to as specification (ibid). This special aspect may be considered more important than any other by the speaker, who therefore highlights it to the addressee without intending to purport negation or emphasis in relation to any other element. This last point distinguishes specification from restriction (see below).

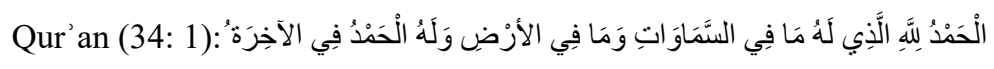

Abdel Haleem: Praise be to God, to whom belongs all that is in the heavens and earth, and praise be to Him in the life to come. $(2004 / 2005$, p.273)

Arberry: ... To Him belongs praise also in the Hereafter; (1955/1998, p.437)

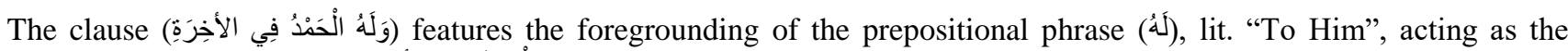

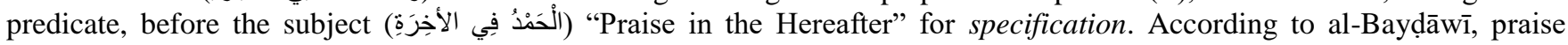
belongs to God specifically in the Hereafter where blessings only come from and through Him, while in life God's blessings may come through people, who deserve to be thanked for offering these blessings to others. 
To render this verse, Arberry foregrounds the object, featuring a marked word order in English whilst Abdel Haleem uses a subjunctive/archaic phrase, which allows him to foreground "praise" rather than "to Him" as in the verse. This structure, common in Christian ceremonial contexts, is not in line with Abdel Haleem's aim of producing a smooth reading translation. 4.2. Restriction (القصر or)

Restriction involves both negation and emphasis: foregrounding for restriction emphasises what is mentioned and negates, at the same time, what is not mentioned. In other words, if an element is foregrounded for restriction, then this element is being emphasised; and other implied elements are simultaneously negated. As such, every marked structure that realises restriction realises, at the same time, emphasis (al-Suyūṭī, 1969 p.189-194; al-Qazwīnī, 1996, pp.126ff; Lāshīn, 1978, p.230). The opposite, however, is not the case.

$$
\text { Qur'an (11:88): : }
$$

Abdel Haleem: ... I cannot succeed without God's help: I trust in Him, and always turn to Him. (2004/2005, p.142)

Arberry: ... in Him, I have put my trust, and to Him I turn, penitent. (1955/1998, p.222, original layout)

According to al-Bayḍāwī and al-Rāzī, the Prophet Shu'aib tells his people in this exchange that success in identifying

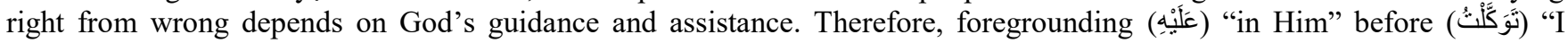
depend" implies that one should only depend on God since only He has power over everything and that no one else has any power in comparison with His. The word order of the verse implies exclusive belief in the oneness of God. Furthermore, the

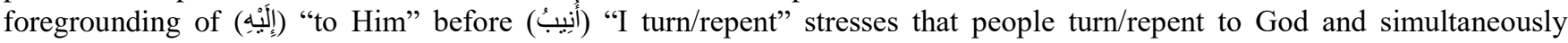
negates that they turn/repent to anyone else.

Arberry foregrounds the object/complement "in Him" and "to Him" to clause-initial position, reproducing the original marked word order. Abdel Haleem uses an unmarked word order to render both cases of foregrounding and opts for a lexical compensation strategy to render the second instance only: he inserts "always," but whether "always," which emphasises continuity, makes up for the force of the relevant clause, which places emphasis on "God," is arguable.

4.3. Emphasis (التوكيب or)

Emphasis, in turn, partly overlaps with restriction, which involves both negation and emphasis. In relation to what is

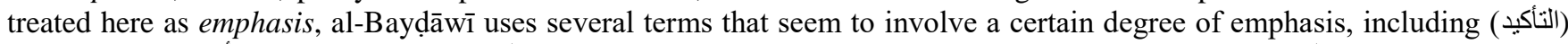
“emphasis," (الأهمية) “importance," (النتبية) “attention-setting," (عناية) “care," (دلالة) "implying." AlBayḍāwī does not explain what he means by each of these categories, which all seem either to be used interchangeably or to indicate a different degree of emphasis. All these labels are subsumed here under emphasis.

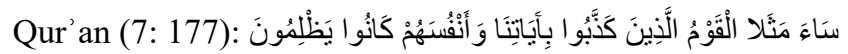

Abdel Haleem: How foul is the image of those who reject Our signs! It is themselves they wrong: (2004/2005, p.107)

Arberry: and themselves were wronging. (1955/1998, p.164)

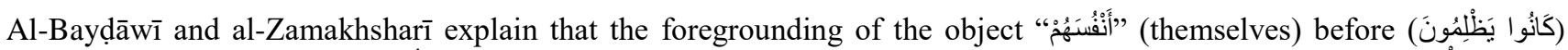

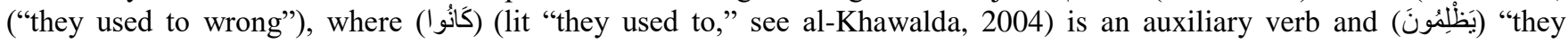
wrong," acting as both verb and subject, implies that they (referring back to the people who deny the Signs God gave to them), "do inflict injustice on themselves by not believing in God" (وما ظلموا بالتكذيب إلا أنفسه). In other words, the negative implications of not believing will only befall them.

Unlike Qur'an (11:88) above, to render this verse, Abdel Haleem uses a cleft structure to emphasise the object. Arberry also emphasises the object by foregrounding it to sentence-initial position.

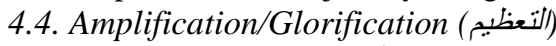

The function of (التعظي)), in its negative sense, means amplification, and, in its positive sense, means glorification, especially when referring to Allah. It is similar to "hyperbole" in English rhetoric.

Qur'an (34: 17): ذللكَ جَزَيْنَاهُمْ بِمَا كَفَرُوا وَهَلْ نُجَازِي إِلا الْكَفُورَ ...

Abdel Haleem: In this way We punished them for their ingratitude - would We punish anyone but the ungrateful? (2004/2005, p.273)

Arberry: Thus, We recompensed them for their unbelief; (1955/1998, p.439) 
Al-Bayḍāwī explains that (ذلِّن (that" refers back to the kind of punishment that was inflicted on the people of Sheba because they rejected God's message, which was delivered to them via thirteen Prophets. He points out that the object (ذلِّ) "that" is foregrounded to sentence-initial position for amplification (النعظيم), i.e. to indicate severe punishment. Al-Rāzī, who does not name the function of this word order, paraphrases the meaning of this verse as follows: (لانجازي بذلك الجزاء إلاً الكفور), "We only punish the non-believers in this manner" (my translation).

Both translations use a marked word order: Abdel Haleem and Arberry foreground the adjuncts "In this way" and "Thus," respectively, to sentence-initial position, mirroring the source language (SL) marked word order and reproducing its force.

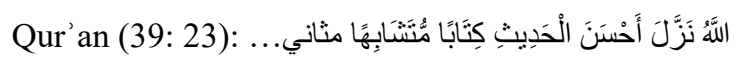

Abdel Haleem: God has sent down the most beautiful of all teachings: a Scripture that is consistent and draws comparisons; (2004/2005, p.297)

Arberry: God has sent down the fairest discourse ... (1955/1998, p.474)

According to al-Bayḍāwī, the above clause features the foregrounding of Allah/God before the verb (نَزَّل) "sent down," creating a nominal rather than a default verbal word order for the glorification of the foregrounded item.

Both translations mirror the word order of the verse but do not reproduce its strength since placing the subject before the verb is the unmarked, nominal word order in English. They do not, however, use any other strategies to reproduce the discursive function of the original.

4.5. Denial (الإنكار)

The function of denial, discussed by al-Bayḍāwī, as well as al-Jurjānī, 1976, pp.142-161; Lāshīn, 1978, p.232 and 288; and al-Qazwīnī, 1904/1996, pp.164ff, occurs in questions rather than statements. To elaborate, word order in questions is motivated by the function the question attempts to fulfil. A question either aims at: (a) "extracting" a statement confirming that an action denoted by the verb was done by the subject, or (b) denying either that the subject is able to do the action or that the action took place at all. Arabic questions are formed in three different ways. First, rising intonation can be used in conversation to change a statement into a question. Second, questions may be formulated through the use of question words, called $M$-interrogatives, which are equivalent to English $W h$-questions. Finally, placing the particles (I) ' $a$ and (ه) $h a l$ at the beginning of a statement changes it into a question. While $M$-interrogatives have to follow regular Arabic word order, questions beginning with the particle ' $a$ can feature either regular or irregular word order. Note that the lexical element occurring after the question particle 'a falls within the scope of "questioning" (see al-Jurjān̄i, 1976, pp.142-161; al-Qazwīnī, 1904/1996, pp.164ff).

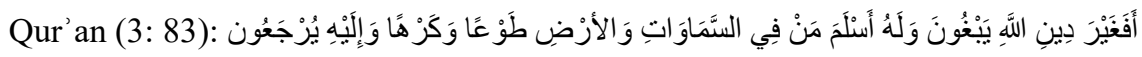

Abdel Haleem: Do they seek anything other than submission to God? Everyone in the heavens and earth submits to Him, willingly or unwillingly; they will all be returned to Him. (2004/2005, p.40)

Arberry: What, do they desire another religion than God's, (1955/1998, p.57)

Al-Bayḍāwī, al-Rāzī and al-Zamakhsharī point out that the object (غَيْرَ) دِينِ (الهَ) “other than God's religion" is foregrounded

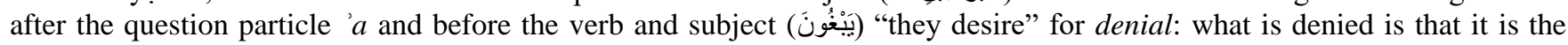
right thing to believe in any deity other than God, especially given that everyone in the heavens and on earth have believed in Him either voluntarily, through contemplation and following proof of God's existence, or involuntarily, convinced by strong signs of His existence. The commentators further explain that the conjunction (ف), “/fa/,"conjoins this verse with the previous one, implying either: a) that those mentioned in the verse above are sinful people since they seek a religion other than God's, or b) that it is questionable whether they believe in God, even after giving an irrevocable pledge to believe in Him and follow His Prophets. Al-Rāzi further adds that since the advent of the Prophet Muhammad was mentioned in the previous Scriptures [e.g. the Bible] as the Qur' an itself states, followers of these Scriptures knew about him but did not follow him out of pride and jealousy. Therefore, God is telling them that seeking to follow a religion other than that of God does not befit rightminded people.

The translators use an unmarked word order, featuring the subject "they," rather than the object, after the auxiliary "do." They opt for lexical compensation to make up for the stylistic effect of the SL foregrounding: Abdel Haleem uses the quantifier "anything" and Arberry "What." Abdel Haleem further foregrounds the proposition of the relevant clause by rendering it as an independent question.

4.6. Multi-function verses

Verses in this category realise more than one of the functions discussed above simultaneously, as in the example below.

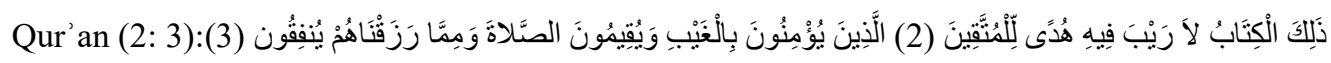


Abdel Haleem: This is the Scripture in which there is no doubt, containing guidance for those who are mindful of God, (3) who believe in the unseen, and keep up the prayer, and give out of what We have provided for them; (2004/2005, pp.4-5)

Arberry: That is the Book, wherein is no doubt,

a guidance to the godfearing who ... expend of that We have provided them; (1955/1998, p.2, original layout)

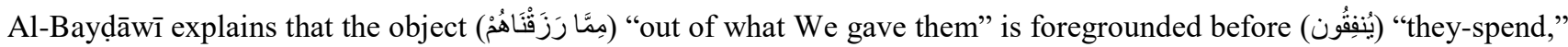

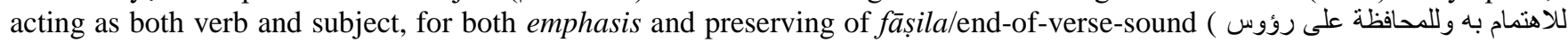
الآي

Both translations feature an unmarked word order to deal with this verse. They make no attempt to reproduce the emphasis placed on the object by foregrounding it to sentence-initial position in the last clause of the verse or through any other strategies.

Table 2 below identifies the strategies used, and the frequency of using them, to deal with the corpus verses. These strategies include, first, using marked English word orders to render the source text (ST) functions. The second strategy is the use of unmarked English word orders, which do not achieve the force of the original. Third, "other word orders" cover instances where it is not possible to identify the use of (un)marked word order, either because (a) the verse lends itself to more than one possible case of declension and the translator concerned opts for rendering the case which features unmarked word order (Qur' an 20: 50 lends itself to two cases of declension, one of which does not feature foregrounding, and it was the latter case that was rendered by the translators and, therefore, this case was not taken into consideration in the final count/percentage of strategies), or (b) the translator opts for a subjunctive/archaic structure that cannot be classified as either marked or unmarked (this features once in each translation). Fourth, the translators use lexical strategies to reproduce, compensate for, and in some cases strengthen, the effect of the original's marked word order. Note that a lexical strategy can either be a lexical addition, if a lexical item is added to the body of the translation without brackets, or an in-text gloss, if the item is added in brackets. The effect in terms of the propositional meaning is the same, but the second case "alerts" the readers to the fact that this particular lexical item does not exist in the original but is implied by its word order.

Table 2: the strategies used by the translators to render the corpus verses $(76$ cases $x 2$ translators $=152$ cases)

\begin{tabular}{|l|l|l|l|l|l|l|l|}
\hline Translator & \multicolumn{2}{|l|}{$\begin{array}{l}\text { SL Function reproduced/compensated for } \\
\text { (57 times) }\end{array}$} & $\begin{array}{l}\text { SL function } \\
\text { not } \\
\text { reproduced } \\
\text { (93 times) }\end{array}$ & $\begin{array}{l}\text { Other } \\
\text { word } \\
\text { orders }\end{array}$ \\
\cline { 2 - 8 } & Cleft & $\begin{array}{l}\text { Cleft } \\
\text { lexical } \\
\text { strategy }\end{array}$ & Preposing & $\begin{array}{l}\text { Preposing } \\
+ \text { lexical } \\
\text { strategy }\end{array}$ & $\begin{array}{l}\text { Unmarked } \\
+ \text { lexical } \\
\text { strategy }\end{array}$ & Unmarked & \\
\hline $\begin{array}{l}\text { Abdel } \\
\text { Haleem }\end{array}$ & 7 & 1 & 4 & 0 & 7 & 56 & $\begin{array}{l}1 \text { NA } \\
\text { archaic }\end{array}$ \\
\hline Arberry & 1 & 0 & 23 & 4 & 10 & 37 & $\begin{array}{l}1 \text { NA } \\
\text { archaic }\end{array}$ \\
\hline Total & 8 & 1 & 27 & 4 & 17 & 93 & 2 archaic \\
\hline Percentage & $37.5 \%$ & & & & & $61.2 \%$ & $1.3 \%$ \\
\hline
\end{tabular}

\section{Contextual Factors behind the Translator's Preferred Strategies}

Having identified the strategies used by the translators and the frequency thereof, I will explore the contextual factors that may have motivated the translators to opt for these strategies, drawing on the translators' stated aims and reviews of their output.

\subsection{Abdel Haleem}

Abdel Haleem acknowledges having used the commentaries drawn on here to identify the verses featuring marked word order and establish their respective functions. He is, therefore, aware of the effect of foregrounding on the meaning of the relevant verse. Nevertheless, Abdel Haleem's translation features the largest number of instances of unmarked word order (63), and the lowest number of instances of marked word order (12) used to render the corpus verses. Note that 8 of the 12 instances of marked word order in his translation feature a cleft structure, which is more common in English than placing an object or a predicate in clause-initial position, for example, as the Arabic text does. Abdel Haleem uses the lowest number of lexical strategies, with 8 instances of added lexical items ("indeed," "alone," "always," "own," "themselves," "anything," "what!" and "what! \& really"), including 7 to compensate for the lost stylistic effect resulting from the use of unmarked word 
order, and once probably unnecessarily because it is used in addition to a cleft structure to render the function of specification which has been reproduced through word order. In other words, he reproduces the SL functions in 19 cases, 11 of which syntactically, 7 through lexical compensation and one case syntactically and semantically.

Abdel Haleem aims to smooth out the intricate SL syntactic structures. This is also evidenced by 13 cases where he renders the relevant clause as an independent sentence/question; a choice that allows him to split too long sentences into smaller, more readable ones. In fact, he argues that he uses punctuation in such a way as to make it simpler for readers to follow the text (Abdel Haleem 2004/2005, pp.xxxiv-xxxv) and, therefore, prefers shorter sentences (ibid, p.xxxv). This is in line with his stated aim to use "a modern, easy style" (ibid, p.xxix) to fulfil the expectations of his intended readership (Abdel Haleem, 2008a). Speaking of word order specifically, Abdel Haleem insists that he avoids the literal rendering of Arabic structures because of the differences between Arabic and English (2008a, 2004a). He, however, uses a subjective structure once, which is a departure from his overall approach.

Abdel Haleem's main motivation is his commitment to Islam. He explains that his earlier academic interests were mainly literary and that his move into Qur'anic studies occurred when he encountered claims by some orientalists about the authenticity of the Qur' an (Abdel Haleem, 2004a). His translation is, therefore, part of his effort to propagate Islam; this aim is best served by offering readers a text which reads fluently. Another possible source of influence on Abdel Haleem is the context in which his translation was produced. There are four points worth mentioning in this respect. First, many of Abdel Haleem's predecessors used archaic language, deterring modern readers from engaging with the Qur'an. Secondly, his translation was produced in an era in which interest in the Qur'an grew in the West, due to growth in the numbers of nonArabic speaking Muslims and converts to Islam (www.pewforum.org). Thirdly, the translation was carried out in an era of "misunderstanding" of Islam and the Qur' an due to the recent rise in Islamophobia. Therefore, Abdel Haleem has a tougher task than Arberry in trying to promote a text which has come to be widely associated with negative stereotypes in the world of his English-speaking readers. Finally, little Arabic literature is translated into English (see Said, 1990), and this, as Baker puts it, "both reflects and reinforces the gap between the two cultures" (2000, p.260).

It is thus understandable that Abdel Haleem considers clarity to be of paramount importance. If he sacrifices some of the Qur'an's formal characteristics, the most important of which is probably word order, he does so in order to offer his readers a clear and familiar text. Reviews of his translation suggest that he has achieved this aim, describing its language as smooth, contemporary, free from archaisms, anachronisms and incoherence (Mohammed, 2005; Rippin, 2004). One criticism of the translation is that it does not create a sense of poetic beauty and fails to reflect the depth and uniqueness of the style of the original (Sardar, 2004). However, the same criticism has been levelled against all other translations of the Qur'an.

\subsection{Arberry}

Arberry aims to reproduce some of the Qur'an's “dramatic impact and most moving beauty" (1955/1998, p.xii) by avoiding "Biblical style" (ibid, p.x). He adopts a dictionary-based translation approach which does not take into account any commentaries, as is the case with Abdel Haleem, resulting in several mistakes arising from misunderstanding the ST. For example, Arberry renders Qur' an (35: 28) as "Even so only those of His servants fear God who have knowledge (1955/1998, p.447)" while Abdel Haleem translates it as "It is those of His servants who have knowledge who stand in true awe of God" (2004/2005, pp.278-9). Focusing on the formal characteristic of word order variations significantly more than Abdel Haleem, Arberry uses a marked word order in 28 cases, of which 24 feature preposing the complement to clause-initial position, producing a comparatively stronger form of inversion than the original, considering that English does not foreground these items very often. That is probably why this translation is described by some reviewers as "slavish" to the original (Abdel Haleem, 2008; Kidwai, 1987; Bausani, 1957). He further uses a topical structure twice, and a cleft structure and a passive structure, once each. Arberry, however, deviates from his close translation approach in 47 cases where he uses an unmarked word order.

Arberry reproduces the force of the original syntactically and/or semantically in 38 cases, including 10 cases where he compensates for the use of a marked word order lexically. Furthermore, he uses a lexical addition in 4 cases, 2 of which to render a multi-function verse, Qur'an (1:5), probably prompted by the desire to reproduce their multiple functions. Arberry uses "what" 8 times, including once together with "indeed"), "only" 2 times, and "all," "do," "forever" and "this," once each. Note that lexical strategies explicitate the syntactic meaning, which is arguably not in line with the literal translation approach adopted here, and Arberry renders the original clause as an independent question/sentence in 9 cases, a choice which arguably foregrounds the whole proposition compared to the ST.

Arberry's background and motivation are significantly different from Abdel Haleem's. He was an orientalist with an academic interest in Arabic and the Qur'an. He was more competent in English, his mother tongue, than in Arabic, and as mentioned above, reviewers have identified occasional mistakes resulting from a misunderstanding of the original (Kidwai, 2007, 1988). Like Abdel Haleem, Arberry does not mention having had his work examined by scholars of Islamic or Qur'anic studies. His work is not motivated by a commitment to propagate Islam but targets an academic readership, who are interested in a word-for-word rendering of the text for study purposes, or in getting a feel for the text itself.

As far as context is concerned, Arberry's translation was produced against a backdrop of several translations which distort the original (e.g. Ross's and Sale's translations, see Kidwai, 2007, p.x, 1987; Mohammed, 2005; Lāwīndī, 2001, pp.19-20). This explains why Arberry attempted to improve on the performance of his predecessors by painstakingly following the word order of the original. However, following Arabic closely occasionally leads to the mistranslation of some verses, as mentioned earlier. For example, (وَهُوَ يُجِيرُ وَلا يُجَارُ عَلَيْهِ) (Qur'an 23: 88), is rendered by Arberry as “protecting and Himself 
unprotected" (1955/1998, p.349), which, Burton (1969, p.388) argues, is not only incorrect but meaningless. Adel Haleem translates this phrase as "Who protects, while there is no protection against Him" (2004/2005, p 21).

The other important feature of Arberry's era is that literary translation dominated the scholarly arena, which explains why Arberry wanted to reflect what he considered to be the most significant feature of the Qur'an, its aesthetic aspects, while remaining "faithful" to the original. Some reviewers consider Arberry's the best translation by a non-Muslim, but also argue that it features some errors of omission and mistranslation, adding that, even with its verse-like format, it does not reflect the spirit of the original (Mohammed, 2005; Kidwai, 1987; Burton, 1969; Bausani, 1957). Abdel Haleem (2008a) argues that Arberry's translation is "great" by comparison to earlier translations, but he stresses that Arberry followed a "hard route" which makes the translation sound foreign, and does not help readers understand the Qur' an (ibid).

\section{Conclusion}

The investigation described above suggests that Abdel Haleem has a tendency to opt for unmarked word order and to make use of punctuation marks in order to produce a natural target text. In the few cases when he uses a marked word order, he prefers cleft structures. His use of additional lexical items to reproduce or reinforce the function of the original word order is markedly less frequent than Arberry's, preserving the same level of implicitness or explicitness as the original. On the other end of the spectrum comes Arberry's translation, which sets out to render the formal characteristics of the Qur'an, featuring a larger number of instances of marked word order and a lower number of instances of unmarked word order. Arberry's focus on the aesthetic qualities of the Qur'an, and, hence, his preference to follow the original word order closely, is indeed evident. His use of 14 additional lexical items is surprising because his is a word-for-word translation approach and one would, therefore, expect him not to add to, or detract from, the original. It is also surprising that reviewers describe this translation as literal and slavish to the original despite all these lexical additions as well as 37 cases where he deviates from rendering the SL marked word order syntactically or otherwise.

The analysis above shows that, firstly, the most common strategy used by the translators to deal with lexical markedness in the corpus is the use of an unmarked word order and losing the SL functions completely, featuring in 93 out of 152 cases (61.2\%). Syntactical and/or semantic strategies are used to render the functions of the SL word in 57 cases (37.5\%), in addition to 2 cases of using an archaic structure (1.3\%). The syntactic strategies used are either a) the foregrounding of the complement (which can be an adjunct, an adverb, an object or a predicate) to sentence-initial position or the use of passive or topical structures (53 times in total), or b) the use of a cleft structure (11 times). The semantic strategies used feature the addition of a lexical item/s, mostly emphasisers and restrictive items, in 17 cases to compensate for the lost stylistic effect due to the use of unmarked word order and in 5 cases together with a marked word order. Secondly, Arberry rarely uses a topical or a passive structure (twice and once each, respectively), the emphasis carrier "do" (only once), which are all common emphasis-creating features in English. Abdel Haleem, on the other hand, never uses any of these features. Furthermore, neither of them uses typography, such as bolding, underlining, or italicisation, which are all used in English for emphasis and attention-setting, or footnotes to elaborate on the issue of word order variation and the function/s thereof.

The above investigation further illustrates that mirroring word order closely does not necessarily produce a marked word order but may results in an unmarked word order in English. For example, Arberry mirrors the word order of Qur' an (14: 47) and (20: 29-30), which feature the foregrounding of the second object before the first object, but reproduces an unmarked word order and losses the relevant SL function. This is because whether or not the indirect object comes before the direct object in English, the result is unmarked word order. See also how both translators mirror the word order of the SL, but present the second object as an apposition of the first in translating Qur'an (20: 29-30). Another example which involves failure to produce the syntactic function through mirroring the SL word order pertains to the verses which feature the foregrounding of the subject before the verb in sentence-initial position (i.e. SVO, as opposed to the unmarked VSO); see Qur'an (2: 269) and (73: 20). Yet one more example involves the location of the adverb in English: in rendering Qur'an (24: 48-49), both translators place the adverb at the end of the clause to mirror the SL word order, but produce an unmarked word order because adverbs have relative freedom of position in English as opposed to Arabic.

Secondly, mirroring the SL word order closely occasionally results in producing a different meaning, for example, Qur'an (2: 249) which speaks of two main groups of followers to Talut: those who drink from the water (who do not belong to Talut) and those who do not drink from the water (and who thus belong to Talut), then excluding those who drink only a handful from the first group. The translators remain very close to the original word order without suggesting any foregrounding but feature three groups of followers: those who drink, those who do not and those who have only a handful of water. Thirdly, not every unmarked word order used by the translators results in foregrounding the item that is foregrounded in the ST or in reproducing the same SL function. For example, in his translation of Qur'an (21: 102), Abdel Haleem preposes the adverb

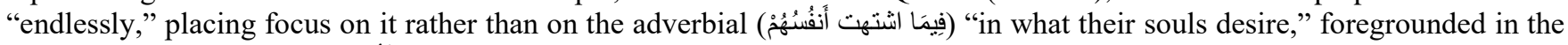
verse before the predicate (خَالِدُونَ) “abide for ever." Fourthly, rendering an equational sentence will be unmarked whether the subject or predicate come in sentence-initial position, see Qur'an (40: 28), posing a challenge to realising the SL foregrounding syntactically.

With respect to lexical additions, these are inconsistently used. The added lexical items sometimes do not relate to the function of the SL structure, leaving one to wonder why they were added in the first place. For example, in translating Qur' an (11: 88), Abdel Haleem adds "always" but this does not communicate the verse's syntactic function. See also Qur' an (21: 
101-2) where Abdel Haleem adds intensifiers which place the focus on a different element from that foregrounded in the original verse. In addition, the translators sometimes use the same lexical item to reproduce different functions, and, even then, they sometimes insert the added lexical item in brackets and sometimes not. One interesting case is Qur'an (1: 5), a multi-function verse, which is translated using both lexical and semantic strategies by Arberry; further evidence that the translator is aware of word order variation and its effect on meaning.

The translators seem to recognise marked word orders and their importance/functions, but differ in terms of how and how often they deal with them. In fact, they are inconsistent, rendering some cases and missing others for no apparent reason. It is also evident that there are restrictions on following the word order of the original because of grammatical consideration sometimes, but the translators mostly do not attempt to compensate for the loss of function semantically or otherwise. In terms of consistency, then, it is difficult to understand why the translators render some stylistic functions but not others or why they use lexical strategies in some examples, especially when they have reproduced the SL function via a marked word order, but not others. The translations generally tend to simplify the intricate grammatical relationships of the original by opting for an unmarked word order and avoiding to raise the relevant syntactic/grammatical issues in footnotes or through any other means; see, for example, how they smooth out the grammatical issues occurring in Qur'an (5: 69), (12: 100) and (21: 3). This tendency can further be seen in the use of punctuation to render clauses as independent sentences/questions, a choice that allows them to split long sentences into shorter, more readable ones. This, however, ties in with the translation universal, which states that translators tend to simplify grammatical structures (Baker, 1995). The issue that this raises then is how the translators justify their respective translation approaches, which seem, in this context, to be relative rather than absolute, an aim rather than a reality.

\section{Acknowledgement}

I would like to thank the following colleagues for their comments on previous versions of this article: H. Bryant, A. Fletcher, F. Louwagie, and K. Malmakjaer.

\section{References}

Abdel-Haleem, M.A.S. (2008a). ترجمة القرآن ليست قرآنا (A translation of the Qur'an is not the Qur'an). www.islamonline.net/servlet/Satellite?c=ArticleA_C\&cid=1225698041388\&pagename=Zone-ArabicShariah\%2FSRALayout

Abdel-Haleem, M.A.S. (2008b). الدكتور عبدالحليم فى حوار لـ 》المصري اليوم) قبيل تكريمه من ملكة بريطانيا (Professor Abdel Haleem in an Interview for al-Masry al-Youm before being Honoured by the Queen) www.almasry-alyoum.com/article2.aspx?Art icleID $=187844 \&$ IssueID $=1236$

Abdel-Haleem, M.A.S. (2004/2005). The Qur'an. (2 $2^{\text {nd }}$ ed). Oxford: Oxford University Press.

Abdel-Haleem, M.A.S. (2004a). عبد الحليم...حامل لنور القرآن في بريطانيا (Abdel Haleem, Bearer of Qur'anic Light in Britain). www.islamonline. net/arabic/famous/2004/06/article05.SHTML

Abdel-Haleem, M. (2004b). English Translations of the Qur'an: The Making of an Image. London: SOAS.

Abdul-Raof, H. (2013). Subject, Theme and Agent in Modern Standard Arabic. London and New York: Routledge.

Al-Bayḍ̄āī, N.A.A.U. (1286.). Anwār al-Tanzīl wa-Asrār al-Ta'wīl (The Lights of Revelation and the Secrets of Interpretation). www.greattafsirs.com

Ali, A.Y. (1934-7/1996). The Meaning of the Holy Qur'ān, New Edition with Revised Translation, Commentary and Newly Compiled Comprehensive Index. Maryland: amana publications.

Al-Jurjān̄i, A. (1976). Dalā'il al-I'jāz (Signs of Inimitability) with Comments and Explanations by Mohamed A. Khafaji. Cairo: Maktabat Al-Qahirah.

Al-Khawalda, M. (2004). The Deterioration of the Usage of 'kaana' in the Holy Quran via Translation. Babel, 50(3), 215229.

Al-Lāwindī, S. (2001). Ishkaliyāt Tarjamat Ma'ān̄̄ al-Qur'ān (The Problems of Translating the Meanings of the Qur'an). Cairo: Markaz al-ḥạ̣āra al-'Arabiya.

Al-Rāzì, M.U.F. (1209). Al-Tafsìr al-Kabīr (The Large Commentary). www.greattafsirs.com

Al-Suyūṭi, J.A. (1969). Mu 'tarak al-Aqrān fi I'jāz al-Qur'ān (Inimitability of the Qur'an), edited by al-Bagawi, M.A. Vol 1. Cairo: Dār al-Fikr al-' Arabī.

Al-Suyūṭị, J.A. (1459-1505). Tafsìr al-Jalālayn (Commentary of the Two Jalāls). www.greattafsirs.com

Al-Suyūṭị, J.A. (1505/1909), Bughyat al-Wu 'ā fì Tabaqāt al-Lughawīȳin wa-al-Nuḥā (Biographies of eminent lexicographers and grammarians). Cairo: Maṭba' at al-Sa'āda.

Al-Qazwīnī, J.A.M. (1904/1996). Al-Jami' fì 'Ulūm al-Balāgha: al-Ma'ān̄̄ wa al-Bayān wa al-Badi' (Clarification of Balāgha Sciences: Meaning, Diction and Rhetoric). Edited by Hussain, A. Cairo: Maktabat al-Adab.

Al-Zamakhsharī, M.U. (1100-1144). Al-Kashshāf (The Revealer). www.greattafsirs.com

Arberry, A.J. (1955/1998). The Koran Interpreted, Translated with an Introduction. Oxford: Oxford University Press.

Asad, M. (1980/2003). The Message of the Qur'an. Bristol: Book Foundation.

Ayoub, M.M. (1992). The Qur'ān and its Interpreters II. Albany: State University of New York Press. 
Ayoub, M.M. (1984). The Qur'ān and its Interpreters I. Albany: State University of New York Press.

Badawi, E., Carter, M. \& Gully, A. (2004). Modern Written Arabic: A Comprehensive Grammar. London: Routledge.

Baker, M. (1995). Corpora in Translation Studies: An Overview and Some Suggestions for Future Research. Target, 7(2), 223-243.

Bausani, A. (1957). On Some Recent Translations of the Qur'an. Numen, 4(1), 75-81.

Bell, R. (1970). Introduction to Islam. Revised and edited by Montgomery, W. Edinburgh: University Press.

Birner, B. \& Ward, G. (1998). Information Status and Noncanonical Word Order in English. Amsterdam and Philadelphia: John Benjamins Publishing Company.

Burton, J. (1969). Review of Companion to the Qur'an: Based on the Arberry Translation by W. Montgomery Watt. Bulletin of the School of Oriental and African Studies, 32(2): 387-389.

Cantarino, V. (1974). Syntax of Modern Arabic Prose, The Simple Sentence, vol I. Bloomington and London: Indiana University Press.

Carter, R. (2004). Language and Creativity: The Art of Common Talk. London and New York: Routledge.

Choi, H. (1996). Optimizing Structure in Context: Scrambling and Information Structure. Doctoral dissertation, Stanford University.

Cuddon, J.A. (1991). The Beguine Dictionary of Literary Terms And Literary Theory (4 ${ }^{\text {th }}$ ed). England: Penguin Books.

Elimam, A.S. (2017). Translating the Qur'an into English: Target Readers' Expectations. Skase Journal of Translation and Interpretation, 11(1), 85-76.

Elimam, A.S. (2013). Marked Word Order in the Qur'an and its English Translations: Patterns and Motivations, New Castle: Cambridge Scholars Publishing.

Elimam, A.S. (2009). Marked Word-Order in the Qur'an: Functions and Translation. Across Languages and Cultures, 10(1).

Green, G. (1982). Colloquial and Literary Uses of Inversion. In Tannen, D. (Ed.). Spoken and Written Language: Exploring Orality and Literacy. Norwood/ New Jersey: Ablex Publishing Corporation.

Guillaume, A. (1956/1990). Islam. Edinburgh: Penguin Books.

Halliday, M.A.K. (2002). Linguistic Studies of Text and Discourse, edited by J. Webster. London and New York: Continuum.

Halliday, M.A.K. (1973). In Explorations in the Functions of Language, London: Edward Arnold.

Harb, L. (2015). Form, Content, and the Inimitability of the Qur'ān in 'Abd al-Qāhir al-Jurjān̄̄'s Works. Middle Eastern Literatures, 18(3), 301-21.

Hilali, M.T. \& Khan, M.M. (1977/1998). Interpretation of the Meanings of The Noble Qur'an in the English Language: Summarized in One Volume. Riyadh/Saudi Arabia: Darussalam Publishers and Distributors.

Kidwai, A. (2007). Bibliography of the Translations of the Meanings of the Glorious Qur'an into English: 1649-2002, A Critical Study. Madinah/Saudi Arabia: King Fahd Printing Complex.

Kidwai, A. (1992). English Translations of the Holy Qur'an, An Annotated Bibliography. http://www.cyberistan.org/islamic/quranetr.htm

Kidwai, A. (1988). English translations of the Holy Quran - An Annotated Bibliography. Hamdard Islamicus, Karachi, Pakistan. 11(4), 47-55.

Kidwai, A. (1987). Translating the Untranslatable: A Survey of English Translations of the Quran. The Muslim World Book Review, 7(4). http://www.quranicstudies.com/printout32.html

Lāshīn, A. (1978). Al-Ma 'anī fì Daw'A Asālīb al-Qur'ān (Meaning in Light of the Qur'anic Style) ( $3^{\text {rd }}$ revised ed). Cairo: Dar al-Ma'ārif.

Lee, H. (2003). Prominence Mismatch and Markedness Reduction in Word Order. Natural Language and Linguistic Theory, 21: 617-680.

Leech, G.N. \& Short, M.H. (1981). Style in Fiction, A Linguistic Introduction to English Fictional Prose. London and New York: Longman.

Leech G.N. (1970). Towards a semantic description of English. USA: Indiana University Press.

Martin-Asensio, G. (2002). Transitivity-Based Foregrounding in the Acts of the Apostles, A Functional Grammatical Approach to the Lukan Perspective. Sheffield: Sheffield Academic Press.

Mohammed, K. (2005). Assessing English Translations of the Qur'an. Middle East Forum, XII(2). http://www.meforum.org/art icle/717

Moutaoukil, A. (1989). Pragmatic Functions in A Functional Grammar of Arabic. Holand and USA: Foris Publications.

Nieuwkerk, K.V. (2006). Women Embracing Islam: Gender and Conversion in the West. Texas: Texas University Press.

Quirk, R. et al. (1997). A Comprehensive Grammar of the English Language (14 $\left.{ }^{\text {th }} \mathrm{ed}\right)$. England: Longman.

Quirk, R. et al. (1989). A Grammar of the English Language $\left(7^{\mathrm{t}} \mathrm{ed}\right)$. London and New York: Longman.

Rippin, A. (2004). Review of Majid Fakhry's An Interpretation of the Qur'an: English Translation of the Meanings and M.A.S. Abdel Haleem's The Qur'an: A New Translation. H-Mideast-Medieval.

Said, E.W. (1990). The Discourse of the Orient. Literature in the Modern World: Critical Essays and Documents. In D. Walder (Ed.). Oxford: Oxford UP \& Open UP, 1990, 234-44.

Sardar, Z. (2004). "Lost in Translation. Most English-Language editions of the Qur'an have contained numerous errors, omissions and distortions. Hardly surprising, writes, when one of their purposes was to denigrate not just the Holy Book, but the entire Islam." Newstatesman. http://www.newstatesman.com/200408090035 
Swan, M. (2005). Practical English Usage. Oxford: Oxford University Press.

Vasalou, S. (2002). "The Miraculous Eloquence of the Qur'an: General Trajectories and Individual Approaches.” Journal of Qur'anic Studies IV(2), 23-53. 